\title{
STATUS GIZI BERHUBUNGAN DENGAN KEJADIAN ISPA PADA BALITA DI PUSKESMAS TANAH TINGGI BINJAI TAHUN 2013
}

\author{
Yulina Dwi Hastuty, Dewi Meliasari, Suswati \\ Jurusan Kebidanan Poltekkes Kemenkes Medan
}

\begin{abstract}
Abstrak
ISPA adalah penyakit saluran pernafasan yang bersifat akut dengan berbagai macam gejala (sindrom) yang disebabkan oleh berbagai sebab, yang terutama mengenai struktur saluran pernapasan diatas laring. Menurut WHO tahun 2012, sebesar $78 \%$ balita yang berkunjung ke pelayanan kesehatan adalah akibat ISPA, khususnya pneumonia. Kematian balita akibat ISPA di Asia Tenggara sebanyak 2.1 juta balita pada tahun 2004. India, Bangladesh, Indonesia, dan Myanmar merupakan negara dengan kasus kematian balita akibat ISPA terbanyak. Tujuan penelitian ini untuk mengetahui hubungan antara status gizi dengan dengan tingkat kejadian ISPA pada balita di Puskesmas Tanah Tinggi Binjai tahun 2013. Penelitian ini adalah penelitian analitik dengan rancangan cross sectional. Dengan menggunakan data sekunder dan primer yang diperoleh melalui catatan rekam medik dan mengukur berat badan balita, yang dilakukan terhadap 53 responden. Teknik pengambian sampel yang digunakan adalah accidental sampling. Data dianalisis menggunakan uji Chi-square. Dari 35 orang balita dengan status gizi tidak baik, mayoritas kejadian ISPA pada balita dengan kategori berat yaitu 23 orang $(65,7 \%)$ dan minoritas dengan ISPA ringan yaitu 2 orang $(5,7 \%)$. Dari 18 orang balita dengan status gizi baik, mayoritas dengan ISPA ringan yaitu 11 orang $(61,1 \%)$ dan minoritas dengan ISPA berat yaitu 2 orang $(11,1 \%)$. Hasil uji chi-square menunjukkan bahwa $p$ value $=0,000<0,05$, artinya terdapat hubungan yang signifikan antara status gizi balita dengan kejadian ISPA pada balita di Puskesmas Tanah Tinggi Binjai.
\end{abstract}

\section{Kata kunci : Status Gizi, ISPA, Balita}

\section{Pendahuluan}

Salah satu target dalam pembangunan milenium atau Millenium Develomment Goals (MDGs) tujuan yang ke 4 yaitu menurunkan angka kematian balita. Target yang ingin dicapai adalah menurunkan angka kematian balita 2/3 dari tahun 1990-2015, sehingga angka kematian bayi menjadi 17/1000 kelahiran hidup dan balita 23/1000 kelahiran hidup pada tahun 2015 (MDG'S,2010).

Penyebab kematian balita umumnya disebabkan seperti penyakit Diare 25,2\%, Pneumonia $15,5 \%$, Enterokolitis 10,7\%, Meningitis 8,8\%, DBD 6,8\%, Campak 5,8\%, Tenggelam 4,9\%, TB 3,9\%, Malaria 2,9\%, Leukimia 2,9\% (Riskesdas,2007).

Menurut WHO tahun 2012, sebesar 78\% balita yang berkunjung ke pelayanan kesehatan adalah akibat ISPA, khususnya pneumonia. ISPA lebih banyak terjadi di negara berkembang dibandingkan negara maju dengan persentase masing-masing sebesar 25\%-30\% dan 10\%$15 \%$. Kematian balita akibat ISPA di Asia Tenggara sebanyak 2.1 juta balita pada tahun 2004. India, Bangladesh, Indonesia, dan Myanmar merupakan negara dengan kasus kematian balita akibat ISPA terbanyak (Usman, 2012).

Kasus pneumonia di negara Amerika, terutama pada bayi menempati urutan ke 6 dari semua penyebab kematian dan peringkat pertama dari seluruh penyakit infeksi. Di Spanyol angka kematian akibat pneumonia mencapai $25 \%$ atau $25-30$ per 100.000 penduduk (Permatasari,2008).

Insiden ISPA dilaporkan sebanyak 3,6 - 6,0\% di Nikaragua, setelah terjadinya letusan gunung berapi kejadian ISPA meningkat sebanyak $2,0-3,6 \%$ pada bayi $<12$ bulan, 2,6 - 6,1\% antara anak 12 bulan -59 bulan, 6,0 7,4\% antara anak-anak 5-14 tahun, 5,2 - 10,0\% antara orang-orang 15-49 tahun, dan 7,7 - 10,0\% antara orangorang $\geq 50$ tahun (WHO,2010).

Kasus ISPA di Indonesia selalu menempati urutan pertama penyebab kematian bayi sebanyak 32,1\% kematian bayi pada tahun 2009, serta penyebab kematian pada balita $38,8 \%$ tahun 2011. ISPA juga sering berada pada daftar 10 penyakit terbanyak di rumah sakit. Berdasarkan data dari pemberantasan penyakit (P2) program ISPA tahun 2009 cakupan penderita ISPA melampaui target, target yang ditetapkan hanya 16.534 kasus tetapi hasil yang di dapat sebanyak 18.749 (13,4\%). Survey mortalitas yang dilakukan di subdit ISPA tahun 2010 menempatkan ISPA/Pneumonia sebagai penyebab kematian bayi terbesar di Indonesia dengan persentase 22,30\% dari seluruh kematian balita (Depkes RI,2012).

Anak dengan gejala ISPA yang dibawa ke petugas kesehatan, sekitar $82,6 \%$ pada usia $<6$ bulan, $88,8 \%$ pada usia $6-11$ bulan, $79,1 \%$ pada usia $12-23$ bulan, $69,2 \%$ pada usia $24-35$ bulan, $75,3 \%$ pada usia $36-$ 47 bulan, dan $67,0 \%$ pada usia 48-90 tahun (SDKI,2012) . 
Kejadian ISPA pada balita di Sumatera Utara pada tahun 2008 yaitu 29,124 kasus. Pada tahun 2009 provinsi Sumatera Utara merupakan provinsi urutan ke empat terbanyak kasus pneumonia pada balita $(21,56 \%)$, setelah provinsi Nusa Tenggara Barat $(71,45 \%)$, Jawa Barat ( 46,16\%) dan kepulauan Banka Belitung (41,41\%) (Safei,dkk, 2008).

Tingginya angka kejadian ISPA pada balita disebabkan oleh beberapa faktor, diantaranya adalah keadaan gizi yang buruk pada bayi dan balita. Balita dengan gizi yang kurang akan lebih mudah terserang ISPA dibandingkan balita dengan gizi normal, hal ini disebabkan tentang penurunan daya tahan tubuh. Penyakit infeksi sendiri akan menyebabkan balita tidak mempunyai nafsu makan dan mengakibatkan kekurangan gizi. Pada keadaan gizi kurang, balita akan lebih mudah terserang ISPA berat bahkan serangan lebih lama (Nuryanto,2009).

Menurut hasil penelitian Nuryanto pada tahun 2010 di wilayah kerja Puskesma Sosial Palembang. Peneliti mengatakan faktor yang berhubungan dengan penyakit ISPA pada bayi adalah status gizi balita, status imunisasi, kepadatan tempat tinggal, keadaan ventilasi rumah, status merokok orang tua, tingkat pendidikan orang tua, tingkat pengetahuan ibu dan sosial ekonomi.

Untuk puskesmas Tanah Tinggi Binjai kasus ISPA cukup banyak dijumpai, rentang waktu antara SeptemberNovember 2013 dijumpai sebanyak 110 kasus. Berdasarkan data tersebut maka penulis tertarik melakukan penelitian tentang hubungan status gizi dengan tingkat kejadian ISPA pada bayi dan balita di puskesmas Tanah Tinggi Binjai tahun 2013.

\section{Rumusan Masalah}

Permasalahan dalam penelitian ini adalah "Adakah Hubungan Status Gizi Dengan Kejadian ISPA Pada Balita Di Puskesmas Tanah Tinggi Binjai”.

\section{Tujuan Penelitian}

Penelitian ini bertujuan untuk mengetahui hubungan antara status gizi dengan dengan tingkat kejadian ISPA pada balita di Puskesmas Tanah Tinggi Binjai tahun 2013

\section{Metode Penelitian \\ Jenis Penelitian}

Penelitian ini bersifat analitik dengan rancangan cross sectional. Penelitian ini mempelajari dinamika korelasi antara faktor-faktor resiko dan efek dengan cara pendekatan, observasi dimana setiap subjek penelitian diobservasi hanya satu kali saja dan pengukuran dilakukan terhadap status karakter atau variabel subjek pada saat pemeriksaan.

\section{Lokasi Dan Waktu Penelitian}

Penelitian ini dilakukan di Puskesmas Tanah Tinggi Binjai pada bulan September-Desember 2013.

\section{Populasi Dan Sampel Penelitian}

Populasi penelitian ini adalah balita yang terdaftar terkena ISPA di Puskesmas Tanah Tinggi Binjai periode bulan September -Nopember 2013 yaitu sebanyak 110 orang. Sedangkan besar sampel penelitian ini ditentukan dengan menggunakan rumus Slovin (Nursalam,2003) dan didapat sampel sebanyak 53 balita dengan Tehnik pengambilan sampel secara accidental sampling yaitu dengan mengambil responden balita yang datang berobat dan terdiagnosa terkena ISPA di Puskesmas Tanah TinggI Binjai.

\section{Metode Pengumpulan Data}

Metode pengumpulan data dilakukan dengan cara mengambil data sekunder dan primer. Data sekunder diperoleh dari catatan rekam medik pasien yang terdaftar terkena ISPA dan data primer diperoleh peneliti dengan mengukur berat badan balita yang datang ke Puskesmas Tanah Tinggi Binjai dengan penyakit ISPA dan dimasukkan ke dummy tabel.

\section{Pengolahan dan Analisis Data}

Data yang diperoleh diedit dan ditabulasi untuk selanjutnya dianalisis secara univariat dan bivariat. Pengujian data dilakukan dengan menggunakan uji statistik Chi Square dengan nilai kemaknaan $(\alpha=0,05)$.

\section{Hasil Penelitian \\ Analisa Univariat}

Berdasarkan hasil yang diperoleh distribusi karakteristik balita yang meliputi umur, jenis kelamin, status gizi dan kejadian ISPA dapat dilihat pada tabel berikut ini :

Tabel 1. Distribusi Karakteristik Balita Di Puskesmas Tanah Tinggi Binjai Tahun 2013

\begin{tabular}{ccc}
\hline Karakteristik Balita & Frekuensi (F) & Persentase $(\%)$ \\
\hline Umur & & \\
1 tahun & 8 & 15,1 \\
2 tahun & 21 & 39,6 \\
3 tahun & 18 & 34,0 \\
4 tahun & 6 & 11,3 \\
\hline Jumlah & 53 & 100,0 \\
\hline Jenis Kelamin & & \\
Perempuan & 25 & 47,2 \\
Laki-laki & 28 & 52,8 \\
\hline Jumlah & 53 & 100,0 \\
\hline Status Gizi & & \\
Tidak Baik & 35 & 66,0 \\
Baik & 18 & 34,0 \\
\hline Jumlah & 53 & 100,0 \\
\hline Kejadian Ispa & & \\
\hline Berat & 25 & 47,2 \\
\hline Sedang & 15 & 28,3 \\
\hline Ringan & 13 & 24,5 \\
\hline Jumlah & 53 & 100,0 \\
\hline
\end{tabular}

\section{Analisa Bivariat}

Hubungan status gizi dengan tingkat kejadian ISPA pada balita dapat dilihat pada tabel berikut ini: 
Tabel 2. Distribusi Hubungan Status Gizi dengan Kejadian ISPA Pada Balita di Puskesmas Tanah Tinggi Binjai Tahun 2013

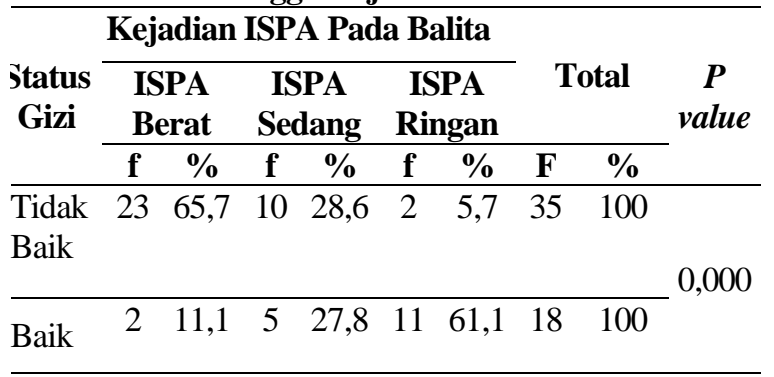

Hasil uji chi-square menunjukkan bahwa $p$ value $=0,000<0,05$, artinya terdapat hubungan yang signifikan antara status gizi balita dengan kejadian ISPA pada balita di Puskesmas Tanah Tinggi Binjai Tahun 2013.

\section{Pembahasan \\ Status Gizi Balita di Puskesmas Tanah Tinggi Binjai Tahun 2013}

Status gizi merupakan faktor yang dapat mempengaruhi secara langsung maupun tidak langsung pada anak. Berdasarkan hasil penelitian diketahui dengan status gizi tidak baik yaitu 35 orang $(66,0 \%)$ dan minoritas dengan kategori baik yaitu 18 orang $(34,0 \%)$. Status gizi yang tidak baik mayoritas disebabkan karena gizi kurang atau tidak sesuainya umur balita sesuai dengan kondisi berat badannya.

Gizi tidak baik yaitu gizi buruk dan gizi lebih. Gizi buruk sederhana akibat KEP (Kurang energi Protein) menyebabkan kelainan seperti Marasmus, Kwasiokor. Gizi lebih yaitu obesitas digolongkan sebagai orang yang mengalami gizi tidak baik. Obesitas adalah kelebihan kalori dan lemak berlebihan. Gizi buruk adalahkekurangan nutrisi berupa protein, karbohidrat, dan kalori.

Terdapatnya kasus malnutrisi pada semua golongan umur balita menunjukkan bahwa malnutrisi pada anak mungkin tidak dapat diatasi sehingga terus berlangsung. Hal ini kemungkin disebabkan karena keadaan sosial ekonomi masyarakat yang kurang baik, ketidaktahuan masyarakat tentang gizi, dan kurangnya peran petugas kesehatan dalam usaha perbaikan status gizi masyarakat. Penanganan gizi buruk sebaiknya tidak hanya difokuskan di pelayanan kesehatan pemerintah saja, namun juga harus disebarluaskan di pelayanan kesehatan swasta karena biasanya tenaga kesehatan yang bekerja di pelayanan kesehatan swasta tidak melaporkan atau bahkan menyadari adanya pasien gizi buruk yang berobat ke tempat mereka. Petugas biasanya hanya terfokus pada penyakit yang dikeluhkan saja. Dengan penyebarluasan informasi mengenai gizi buruk di pelayanan kesehatan swasta akan membuat tenaga medis yang bekerja di tempat tersebut lebih peduli sehingga dapat membantu mengatasi masalah gizi buruk di masyarakat. Tenaga kesehatan harus sering turun ke lapangan untuk memberikan penyuluhan langsung kepada masyarakat terutama pada kaum ibu tentang masalah gizi sehingga meningkatkan pengetahuan dan kesadaran masyarakat akan pentingnya zat gizi untuk anak-anak mereka.
Berdasarkan hasil penelitian umur balita yang banyak terkena yaitu umur 2 tahun. Hal ini membuktikan bahwa pada usia 2 tahun daya tahan tubuh belum terlalu kuat sehingga mudah terkena ISPA. Hal ini sejalan dengan hasil penelitian Kartasasmita di Cikutra (1993) bahwa insieden dan lamanya anak menderita ispa menurun dengan bertambahnya umur. Dari hasil penelitian juga didapat lebih banyak jenis kelamin laki-laki yang terkena ISPA. Ada sebagian sumber mengatakan bahwa ada kecenderungan anak laki-laki lebih sering terserang infeksi dari pada anak perempuan, tetapi belum dapat dijelaskan secara pasti antara faktor genetik atau dalam pemberian makanan.

\section{Kejadian ISPA Pada Balita di Puskesmas Tanah Tinggi Binjai Tahun 2013}

Penyakit infeksi mudah menyerang pada balita dengan keadaan gizi kurang. Berdasarkan hasil penelitian diketahui mayoritas kejadian ISPA pada balita dengan kategori berat yaitu 25 orang $(47,2 \%)$ dan minoritas balita dengan ISPA ringan yaitu 13 orang (24,5\%).Banyaknya kejadian ISPA berat yang dialami balita disebabkan karena adanya gangguan metabolisme tubuh akibat kekurangan energi dan protein, sehingga menyebabkan daya tahan tubuh semakin berkurang. Hal ini sesuai dengan hasil penelitian Putri (2012) bahwa kejadian ISPA pada balita akan memberikan gambaran klinik yang lebih berat dan buruk. Hal ini disebabkan karena ISPA pada anak balita umumnya merupakan kejadian infeksi pertama serta belum terbentuknya secara optimal proses kekebalan secara alamiah. Pada orang dewasa sudah banyak terjadi kekebalan alamiah yang lebih optimal akibat pengalaman infeksi sebelumnya.

Menurut penelitian Muluki (2003), diketahui bahwa status gizi merupakan faktor resiko yang sangat berpengaruh terhadap kejadian ISPA dibandingkan faktor resiko status imunisasi, status ASI eksklusif dan berat badan lahir rendah. Balita yang mengalami gizi buruk lebih mudah terserang penyakit.

Berdasarkan penelitian Susie (2001), infeksi saluran pernapasan akut merupakan penyakit yang paling banyak diderita oleh balita yang menderita gizi buruk dibandingkan penyakit lainnya

Gizi yang buruk akan mempermudah balita terserang ISPA. Beberapa penelitian telah membuktikan tentang adanya hubungan antara gizi buruk dan infeksi paru, sehingga anak-anak yang bergizi buruk sering mendapat pneumonia.

Balita yang terkena ISPA memiliki faktor-faktor resiko antara lain faktor usia dan status gizi. Faktor usia kejadian ISPA banyak terjadi pada usia 2 tahun mempunyai resiko mendapat ISPA lebih besar dari pada anak yang lebih tua, karena pada usia tersebut kekebalan tubuh anak belum optimal. Balita yang terkena ISPA akan mengalami penurunan nafsu makan dan mengakibatkan kekurangan gizi. Pada saat gizi kurang balita lebih mudah terkena penyakit ISPA berat.

Hubungan Status gizi dengan Kejadian ISPA Pada Balita di Puskesmas Tanah Tinggi Binjai Tahun 2013 
Berdasarkan hasil penelitian pada uji bivariat diketahui dari 35 orang balita dengan status gizi tidak baik, mayoritas kejadian ISPA pada balita dengan kategori berat yaitu 23 orang $(65,7 \%)$ dan minoritas dengan ISPA ringan yaitu 2 orang $(5,7 \%)$. Dari 18 orang balita dengan status gizi baik, mayoritas dengan ISPA ringan yaitu 11 orang $(61,1 \%)$ dan minoritas dengan ISPA berat yaitu 2 orang $(11,1 \%)$. Maka semakin tinggi status gizi balita yang tidak baik semakin banyak yang terkena ispa berat.

Pada balita dengan kategori gizi tidak baik tetapi mengalami ISPA ringan, disebabkan gizi tidak baik pada balita bukan disebabkan karena gizi kurang, tetapi karena gizi lebih sehingga ISPA yang terjadi pada balita bukan hanya disebabkan karena faktor konsumsi energi saja tetapi karena pengaruh faktor lingkungan rumah dan sekitarnya yang tidak sehat. Sedangkan balita dengan status gizi baik tetapi masih ada balita dengan ISPA berat disebabkan karena adanya anggota keluarga yang terkena pilek, sehingga tertular pada balita. Hal ini sesuai dengan pendapat Putri (2012) bahwa apabila dalam satu rumah anggota keluarga terkena pilek, balita akan lebih mudah tertular. Dengan kondisi anak yang lemah, proses penyebaran penyakit menjadi lebih cepat.

Hasil uji chi-square menunjukkan bahwa $p$ value sebesar $=0,000$ artinya terdapat hubungan yang signifikan antara status gizi balita dengan kejadian ISPA pada balita di Puskesmas Tanah Tinggi Binjai Tahun 2013. Adanya interaksi sinergistik antara malnutrisi dan infeksi. Infeksi yang berat dapat memperburuk status gizi melalui gangguan masukan/konsumsi makanan dan meningkatkan kehilangan zat-zat essensial tubuh. Sebaliknya malnutrisi meskipun ringan berpengaruh buruk pada daya tahan tubuh terhadap infeksi.

Hal ini sejalan dengan hasil penelitian Nugroho (2006) yang menyatakan bahwa salah satu faktor resiko yang menyebabkan ISPA adalah balita dengan kurang gizi, balita yang tidak mendapat ASI memadai dan defisiensi vitamin A. Sebagai faktor yang meningkatkan angka mortalitas adanya gizi kurang. Hal yang sama juga dikemukakan dari hasil penelitian Sulistyoningsih dan Rustandi (2010) bahwa ada hubungan antara gizi buruk dengan infeksi paru, sehingga anak-anak yang bergizi buruk sering mendapat ISPA. Balita dengan gizi yang kurang akan lebih mudah terserang ISPA dibandingkan balita dengan gizi normal karena faktor daya tahan tubuh yang kurang. Penyakit infeksi akan menyebabkan balita tidak mempunyai nafsu makan dan mengakibatkan kekurangan gizi. Pada keadaan gizi kurang, balita lebih mudah terserang ISPA berat bahkan serangannya lebih lama.

Keadaan gizi yang tidak baik muncul sebagai faktor resiko untuk terjadinya ISPA. Beberapa penelitian telah membuktikan tentang adanya hubungan antara gizi tidak baik dengan infeksi sehingga anak-anak yang bergizi buruk sering terkena ISPA. Daya tahan tubuh anak yang kurang gizi menurun sehingga mudah terkena penyakit infeksi, anak yang menderita infeksi akan mengalami gangguan nafsu makan dan penyerapan zat gizi sehingga menyebabkan kurang gizi. Penurunan status gizi yang terjadi terkait dengan penurunan asupan makanan akibat gangguan kesulitan makan. Anak dengan pneumonia berat dapat mengalami kesulitan makan karena adanya pernafasan cepat dan sulit bernafas. Jika pemberian suplai makanan yang dikonsumsi oleh anak balita baik maka status gizi anak balita itu juga ikut membaik. Namun menkonsumsi makanan yang baik tidak cukup untuk membuat status gizi anak balita menjadi baik, tetapi anak balita itu harus selalu sehat dan tehindar dari penyakit infeksi (ISPA). Oleh sebab itu penyakit infeksi dapat mempengaruhi status gizi anak balita dan status gizi juga dapat menyebabkan timbulnya penyakit

\section{KESIMPULAN DAN SARAN}

\section{Kesimpulan}

Berdasarkan hasil penelitian mengenai

"Hubungan Antara Status Gizi Dengan Dengan Tingkat Kejadian ISPA Pada Balita di Puskesmas Tanah Tinggi Binjai Tahun 2013, maka disimpulkan sebagai berikut :

1. Status gizi balita mayoritas dengan status gizi tidak baik yaitu 35 orang $(66,0 \%)$ dan minoritas dengan status gizi baik yaitu 18 orang $(34,0 \%)$.

2. Balita mayoritas menderita ISPA berat yaitu 25 orang $(47,2 \%)$ dan minoritas menderita ISPA ringan yaitu 13 orang $(24,5 \%)$.

3. Hasil analisa Chi-square diketahui terdapat hubungan antara status gizi dengan dengan tingkat kejadian ISPA pada balita dengan nilai $p$ value sebesar $0,000<$ 0,05

\section{Saran}

- Diharapkan kepada instansi terkait untuk dapat meningkatkan pelayanan pada balita terutama meningkatkan informasi tentang penyakit infeksi pada balita dan cara hidup sehat, agar dapat mengurangi resiko balita terkena infeksi seperti ISPA yang dapat mempengaruhi status gizi balita.

- Penelitian ini perlu dilanjutkan untuk melihat factor-faktor lin yang juga memiliki peran terhadap peningkatan kejadian ISPA pada balita.

\section{DAFTAR PUSTAKA}

Agustanti, 2012 Dinkes Sulawesi Selatan http://dinkesSulsel.go.id/new/index.php?option=c om content\&task=view\&id=932\&Itemid=1 \{accessed 31 maret 2013]

Badan Pusat Statistik : Laporan Pendahuluan Survei Demografi dan kesehatan Indonesia 2012, Kementrian kesehatan

Behrman dkk, 2000 Nelson Ilmu Kesehatan Anak, Jakarta : Penerbit Buku Kedokteran EGC

DepKes RI. Direktorat Jenderal PPM \& PLP. Pedoman Pemberantasan Penyakit InfeksiSaluran Pernafasan Akut (ISPA). Jakarta. 2012

Hartono, R dan Rahmawati D, 2012. ISPA Gangguan Pernafasan Pada Anak. Yogyakarta: Nuha Medika

Manurung, S. et al., 2009. Gangguan Sistem Pernafasan Akibat Infeksi. Jakarta : Trans Info Medica 
Marimbi, H, 2010 Tumbuh Kembang, Status Gizi, dan Imunisasi Dasar Pada Balita, Nuha Medika, Yogyakarta

Maryunani,A.2010. ilmu kesehatan anak dalam kebidanan TIM, Jakarta

MDG"s,2010. The Millennium Development Goals Report http://www.un.org /millenniumgoals/pdf/MDGReport2010Enr15lowres201006152.pdf [accesed 07-07-2013]

Mukono, H, 2008. Pencemaran Udara dan Pengaruhnya Terhadap Gangguan Saluran pernafasan, Airlangga Universitas Press, Surabaya

Muluki (2003) Analisis faktor risiko yang berhubungan dengan terjadinya penyakit ISPA di Puskesmas Palanro Kecamatan Mallusetasi Kabupaten Barru Tahun 2002-2003. 2003. Badan Penelitian dan Pengembangan Kesehatan Departemen Kesehatan.

Notoatmodjo, S, 2010 Metode Penelitian Kesehatan , Rineka Cipta, Jakarta

Nugroho, S. 2006. Hubungan Antara Status Gizi Balita Dengan Kejadian Ispa Di Desa Wonoboyo Wilayah Kerja Puskesmas Wonoboyo Kabupaten Temangun. www.unimus.ac.id [accesed 23-07-2013]

Nuryanto,A, 2012. Hubungan Status Gizi Terjadap Terjadinya Penyakit Infeksi Saluran Pernafasan Akut [online] balitbangnovda.sumselprov.go.id/data/download/ 20121227173330.pdf [accesed 31-03-2013]

Nursalam. 2003. Konsep dan penerapan metodologi penelitian keperawatan. Jakarta

Putri,2012. Faktor lingkungan yang berhubungan dengan kejadian ISPA pada balita dan perbedaan kondisi lingkungan pada balita yang mengalami ISPA www.eprint.uny.ac.id.

Permatasari,C., 2008. Faktor Resiko Kejadian Gejala ISPA Ringan Pada Balita Di Rangkapan Jaya Baru Kota Depok Tahun 2008 [online] Available at < http://lontar.ui.ac.id/file?file=digital/126838-S5827-Faktor\%20risiko-HA.pdf> [accesed 31-032013]

Rahajoe, N. 2008. Buku Ajar Respirologi Anak. Edisi Pertama. Badan
Penerbit IDAI. Jakarta

Riwu, D, 2012, ISPA menduduki peringkat pertama penyakit terbesar tahun 2011. Times Online, [online] 29 February t,Available At : http://www.dinkes-kotakupang.web.id/wartadinkes/175-ispa-duduki-peringkat-pertamapenyakit-terbesar-tahun-2011.html

RISKESDA,2007. Buletin Jendela Epidemiologi Pneumonia Balita Volume 3, September 2010 http://www.depkes.go.id/downloads/publikasi/bul etin/BULETINPNEUMONIA.pdf $>$ [accesed 1207-2013]

Safei,dkk, 2008 profil kesehatan propinsi Sumatera Utara Dinkes SUMUT Medan

Simarmata, D., 2009. Kajian Ketersediaan Pangan Rumah Tangga, Status Ekonomi Keluarga, Pengetahuan Gizi Ibu dengan Status Gizi Anak Balita di Wilayah Kerja Puskesmas Melati Kecamatan Perbaungan Tahun 2009.Skripsi, Fakultas Kesehatan Masyarakat Universitas Sumatera Utara, Medan.

Soekirman. 2000. Ilmu Gizi dan Aplikasinya untuk Keluarga dan Masyarakat Ditjen Dikti. Jakarta. Departemen Pendidikan Nasional.

Sulistioningsih dan Rustandi Faktor-Faktor Yang Berhubungan Dengan Kejadian Ispa Pada Balita Di Wilayah Kerja Puskesmas DTP Jamasin Kabupaten Tasikmalaya Tahun 2010. http://Sulistioningsih 2010_Journal. unsil.ac.id [accesed 23-07-2013]

Supariasa, I, dkk 2008, Penilaian Status Gizi, Jakarta : Penerbit Buku Kedokteran ECG

Usman, Iskandar. 2012. Penderita ISPA. http://repository.unhas.ac.id/bitstream/handle/123 456789/4279/RIBKARERUNGLAYUK(K1110 9326).pdf?sequence=1 (Accesed 12-07- 2013)

Widoyono, 2011 Penyakit Tropis, edisi kedua Erlangga, Jakarta

WHO. 2010, conflict and health [online] Available at :http://www.who.int/entity /diseasecontrolemergencies/publications/Burdeno $\underline{\text { facuterespiratoryinfections.pdf }}$ 